\section{Review of the land subsidence hazard in Pekalongan Delta, Central Java: insights from the subsurface}

Rudarsko-geološko-naftni zbornik

(The Mining-Geology-Petroleum Engineering Bulletin) UDC: $551.3 ; 556.3$

DOI: 10.17794/rgn.2021.4.13

Professional paper

\author{
DwiSarah'; EkoSoebowo'; Nugroho Aji Satriyo' \\ ${ }^{1}$ Research Center for Geotechnology, Indonesian Institute of Sciences (LIPI), Jl. Sangkuriang Gd 70, Bandung 40135, Indonesia
}

\begin{abstract}
Land subsidence is a global threat to coastal areas worldwide, including the North Java coastal area. Of many areas experiencing land subsidence in North Java, the rate of land subsidence in Pekalongan has matched the high subsidence rates usually found in big cities. The rate of land subsidence in Pekalongan far exceeds the sea-level rise, resulting in a looming threat of land loss. The devastating impacts of land subsidence are the manifestation of its subsurface movement. Therefore, it is essential to understand the subsurface to elucidate the mechanism of land subsidence. Previous studies on land subsidence in Pekalongan are mainly related to subsidence rate monitoring and have not elaborated on the subsurface condition. This paper reviews the Pekalongan subsurface geology based on available literature to provide insight into the land subsidence problem. The results revealed that the land subsidence occurs in the recent alluvial plain of Pekalongan, consisting of a 30-70m thick compressible deposit.Possible mechanisms of land subsidence arise from natural compaction, over-exploitation of confined groundwater, and increased built areas. As the seismicity of the study area is low, tectonic influence on land subsidence is considered negligible. It is expected that the offshore, nearshore, and swamp deposits are still naturally compacting. As the surface water supply is minimal, over-exploitation of groundwater resources from the deltaic and Damar Formation aquifers occurs. In the end, future research direction is proposed to reduce the impacts of the subsidence hazard.
\end{abstract}

\title{
Keywords:
}

land subsidence; Pekalongan;subsurface; alluvial deposit; compressible

\section{Introduction}

The deltaic region is highly susceptible to risks exposed from local human activities, sea-level rise, land subsidence, storms and flooding, and an increase in groundwater salinity. Although the deltaic region only accounts for $1 \%$ of the global land area, it is home to approximately $7 \%$ of the world population (Ericson et al., 2006). The large and flat deltas are attractive for anthropogenic activities, and many have become population centres, some of which rapidly grow into megacities (Syvitski, 2008). In recent years, land subsidence has become a significant threat to the sustainability of the low-lying deltaic areas (Syvitski et al., 2009). Land subsidence is the lowering of the earth's surface that can occur either naturally or due to human intervention, or by both natural and human-made causes (Galloway and Burbey, 2011). Land subsidence usually occurs in flat terrains where sediments accumulate in alluvial basins or coastal plains. The underlying sediments are unconsolidated and suffer from external stresses from groundwater overexploitation and, rapid physical development.

Corresponding author: Dwi Sarah

sarahpr28@gmail.com
A systematic literature review shows that land subsidence incidences have occurred at 200 locations in 34 countries, and most of the population exposed to subsidence resides in Asia (86\%) (Herrera-García et al., 2021). Although global sea-level rise also poses a threat to the coastal lowland, a more critical hazard is forthcoming: the subsidence of flat deltaic plains, particularly in Southeast Asia (Schmidtz, 2015). Combined impacts from global sea-level rise and local land subsidence in deltas are devastating, causing permanent submergence, frequent flooding, loss of land, increased buildings and infrastructures maintenance costs, and other associated damages. The global average sea-level rise occurs at 3.3 $\mathrm{mm} /$ year and is expected to rise to $8-16 \mathrm{~mm} /$ year during 2081-2100 under the RCP 8.5 scenario (Church et al., 2013). Local sea-level rise may differ from the global average rate, and some parts of the ocean may experience lower and higher rates. The rate of local sea-level rise may be due to the increase in sea surface height (tides, storms, climate variability) or the decrease in land elevation (e.g., land subsidence) (Mimura, 2013). The local land subsidence in the deltaic region aggrandizes the impacts of the local sea-level rise. The deltas in Southeast Asia are vulnerable to the devastating impacts of combined hazard of land subsidence and sea-level 


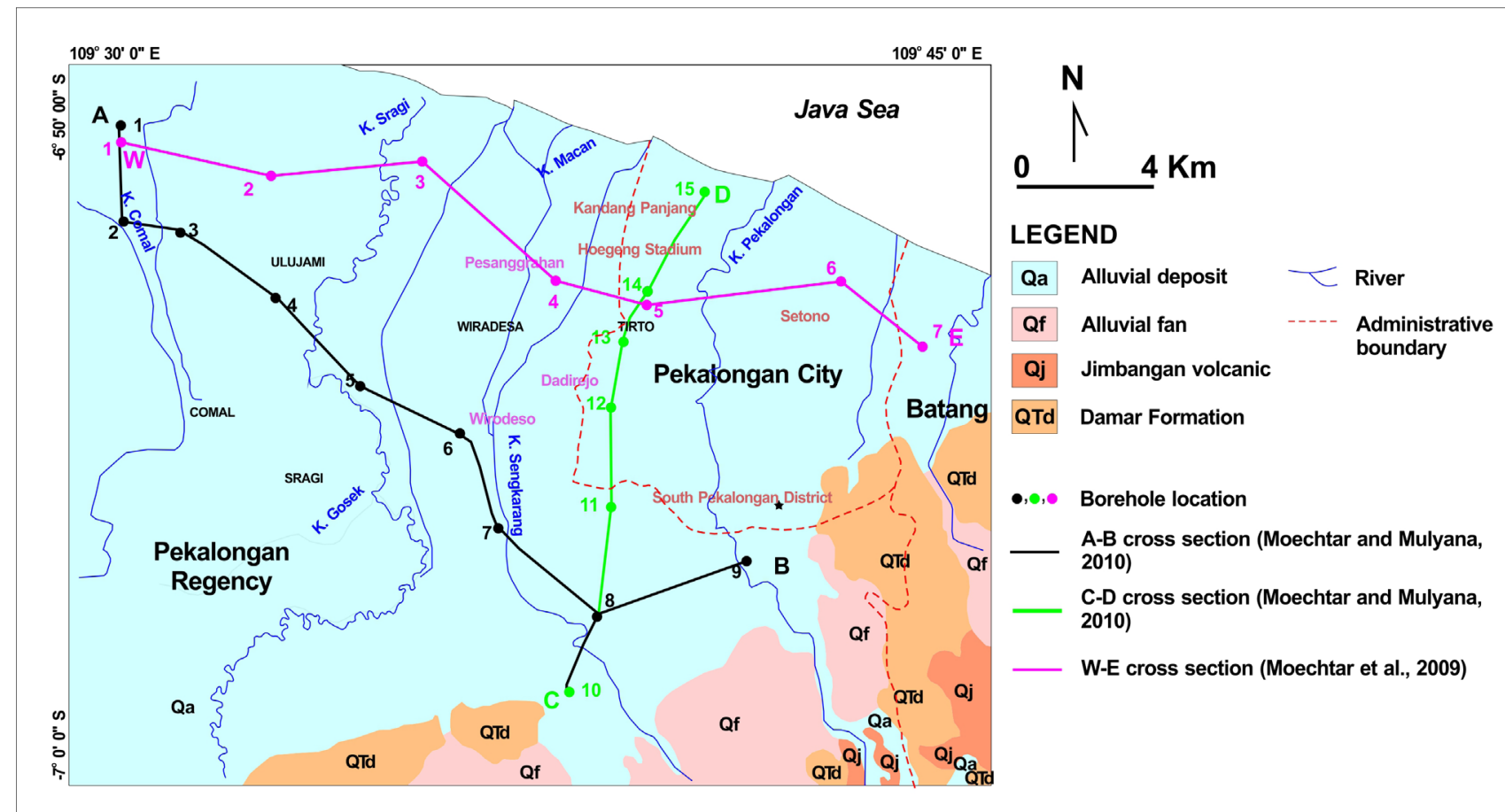

Figure 1: Geological map of study area (Condon et al., 1996)

rise with the rates of land subsidence exceed the rate of average global sea-level rise by 10 -times of or more, for example, the average land subsidence rates in Jakarta (4 $\mathrm{cm} /$ year) (Hakim et al., 2020), Semarang (5 cm/year) (Irawan et al., 2021), Mekong delta $(5 \mathrm{~cm} /$ year) (de Wit et al., 2021).

In Southeast Asia and globally, Indonesia counts as one of the countries with a highly exposed population to land subsidence and sea-level rise hazards, with nearly $60 \%$ of its population living near the coast (Cao et al., 2021; Herrera-García et al., 2021). Twenty-one provinces comprising 134 districts in Indonesia have land subsidence problems (Andreas et al., 2019a), with the most pronounced subsidence taking place in the north coast of Java and the east coast of Sumatra. Land subsidence in North Java affects almost the entire north coast, particularly the coastal cities, such as Jakarta, Bekasi, Pekalongan, Semarang, Surabaya (Andreas et al., 2019a; Sarah \& Soebowo, 2018).

The north coast of Java comprises an extensive coastal lowland belt extending from west to east bordering the Java Sea and is composed of alluvial deposits of Quaternary unconsolidated clay, silt, sand, and gravels (Van Bemmelen, 1949). The alluvial deposits in the North Java coast form multi aquifer-aquitard layers, where the aquifer occurs as lenses, and the upper aquitard is mainly soft and highly compressible (Sarah \& Soebowo, 2018). As the cities along the North Java coast continue to overgrow, utilization of groundwater becomes inevitable. Over-exploitation of groundwater leads to a decline of the aquifer water-level. As this process proceeds, the overlying aquitard would adjust itself to the reduced groundwater head by releasing water from its pores, causing compaction known as land subsidence. The land subsidence hazard works on a local scale; its characteristics and mechanism depend on the local geology and hydrogeology, material properties, land use, and the typical anthropogenic use of groundwater. Land subsidence in Jakarta and Semarang cities is relatively wellknown for its characteristics, such as land subsidence rates and monitoring, subsurface geology, mechanism, and predictive modeling, and its relationship to policymaking and mitigation. An emerging land subsidence hazard is identified in Pekalongan City, where the land subsidence rate is quite high at 10-14 cm/year (Andreas et al., 2020), on par with the maximum subsidence rates in big cities of Jakarta and Semarang. Limited studies have been conducted in Pekalongan related to land subsidence. Therefore, this paper aims to present a comprehensive review of the Pekalongan geology to provide insight into the land subsidence problem. In the end, a future research direction is proposed.

\section{Study Area and Land Subsidence Problem}

Pekalongan area is a deltaic area formed by the Pekalongan, Sragi, and Comal rivers, situated at coordinates $109^{\circ} 30^{\prime} 0^{\prime \prime} \mathrm{E}-109^{\circ} 45^{\prime} 0^{\prime \prime} \mathrm{E}$ to $-6^{\circ} 50^{\prime} 0^{\prime \prime} \mathrm{S}$ to $-7^{\circ} 0^{\prime} 0^{\prime \prime} \mathrm{S}$ (see Figure 1). Administratively, the Pekalongan area is divided into two separate regions, Pekalongan City, and Pekalongan Regency, belonging to Central Java Province. Pekalongan City is the primary node of the Petanglong (Pekalongan City- Batang Regency- Pekalongan Regency) area network that serves as the national strate- 


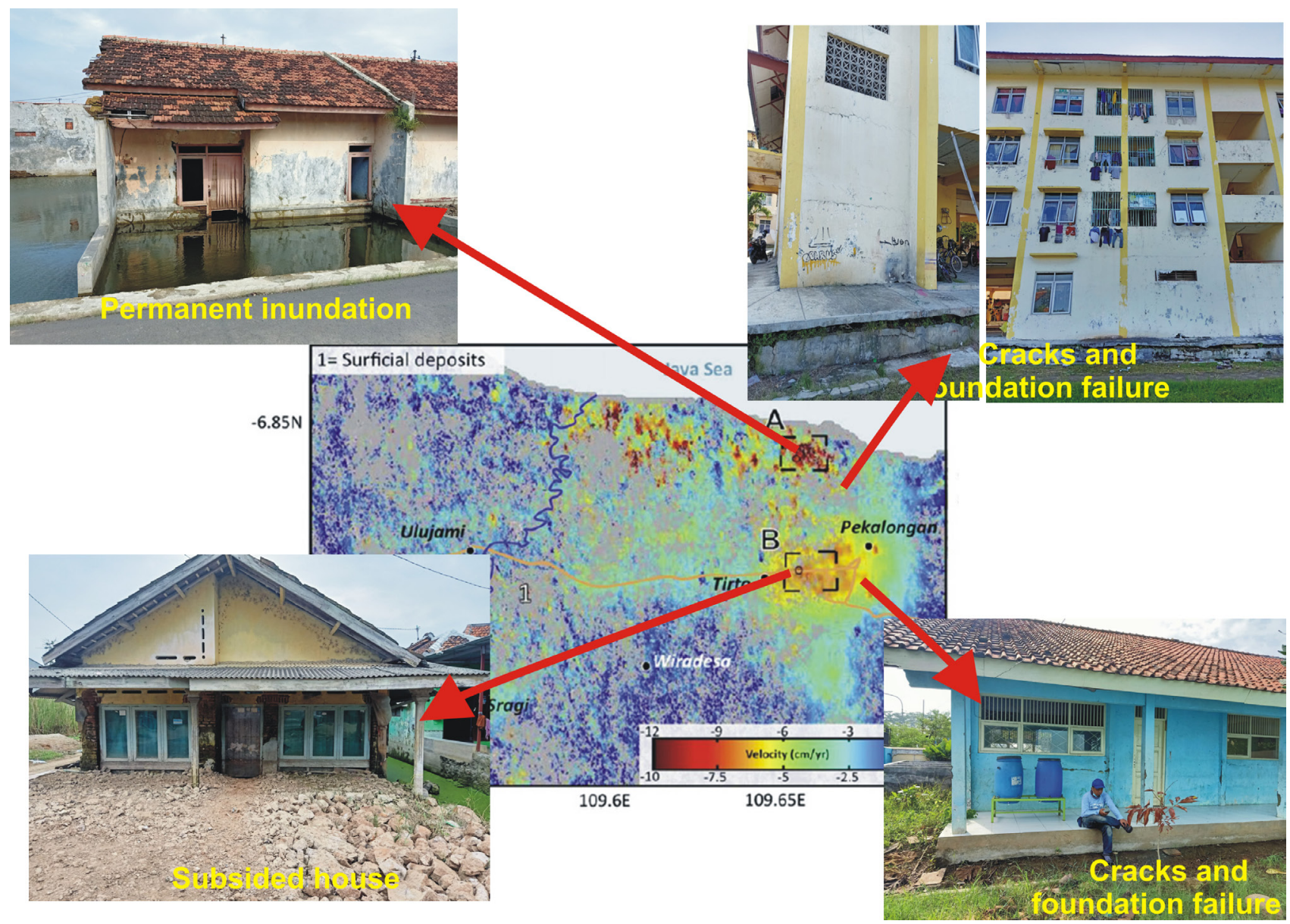

Figure 2:Impacts of land subsidence in Pekalongan and their locations on the subsidence rate map (from Chaussard et al.,2013)

gic corridor for regional development. Pekalongan comprises an extensive lowland in the north coast extending from west to east over a width of approximately $27 \mathrm{~km}$, consisting of the alluvial deposit of river, beach, and lake deposits of Quaternary age (Condon et al., 1996) (see Figure 1). The south and southeast of the study area are of higher elevation, consisting of the alluvial fans from the volcanic debris deposit (Qf), volcanic rocks of Jimbangan Formation (Qj), and Damar Formation (QTd). The major rivers flowing through the study area are the Pekalongan, Sengkarang, Sragi, and Comal rivers. The rivers flow towards the north with an almost parallel pattern.

Pekalongan City and Pekalongan Regency have a combined population of 1.2 million in 2020, with a population density of $6,966.14$ people $/ \mathrm{km}^{2}$ and $1,158.72$ people $/ \mathrm{km}^{2}$, respectively (URL1, URL2). The land subsidence problem is widely evident in Pekalongan City and sparsely occurs in Pekalongan Regency, in particular on the north coast (Chaussard et al., 2013). The subsidence rate has increased from 7.7-10.5 cm/year in 2009 (Chaussard et al., 2013) to 10-14 cm/year in 2015 (Andreas et al., 2020). As a medium-sized city, the land subsidence rate in Pekalongan has matched the subsid- ence rates of the more populous and built megacity of Jakarta and the Central Java provincial capital of Semarang. Pekalongan City is located almost entirely on the alluvial plain of the north coast of Java. Rapid development had occurred to accommodate the growing population and economic activities, resulting in an increase of built-up land at arate of 170.544 hectares/year during 2017-2019; the built-up land accounts for $57.75 \%$ of the total city area (Bashit et al., 2020).

Clean water is definitely high in demand to sustain the development of the Pekalongan area. Clean water sources in the Pekalongan alluvial plain come from surface water and groundwater. As surface water source is limited, generally, people rely on groundwater from both unconfined and confined aquifers (Widada, 2007). Studies from Widada (2007) indicated that groundwater salinization had occurred at the shallow unconfined aquifer. The salinization of unconfined groundwater indirectly forces the community and industries to dig deeper to obtain water from a confined aquifer. Chaussard et al. (2013) observed that the spatial pattern of the land subsidence in the north coast of Pekalongan coincides with agricultural areas, which suggests that groundwater extraction occurs for agricultural use. 
A (West)

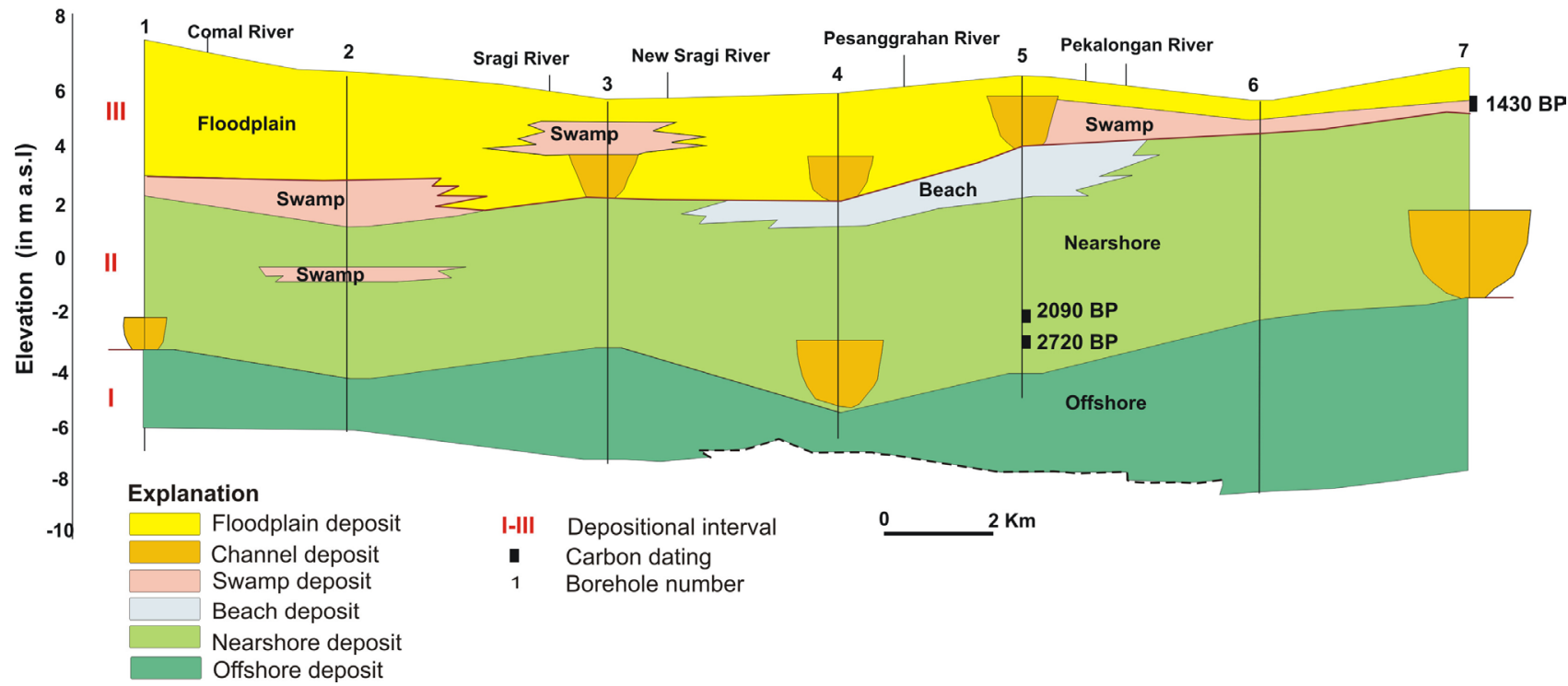

Figure 3: West-East section of the Quaternary sediment in Pekalongan (from Moechtar et al.,2009)

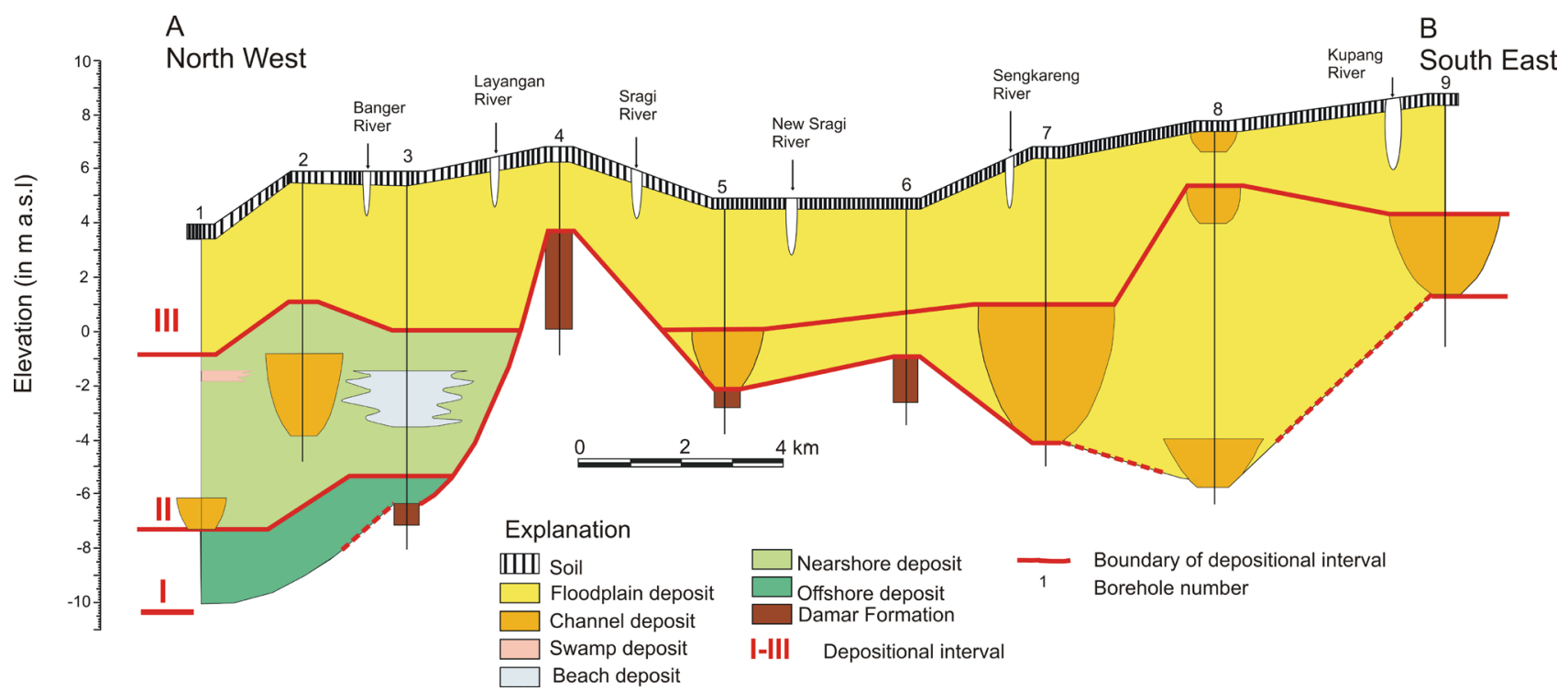

Figure 4: Northwest-Southeast section of the Quaternary sediment in Pekalongan (from Moechtar and Mulyana, 2010)

From the standpoint of the land subsidence mechanism, two causes of land subsidence can be inferred. First is the increase of built-up area, which stresses the upper Quaternary alluvium, and the stress from the subsurface is caused by natural compaction and dewatering of the aquifer system. The impacts of the land subsidence in the Pekalongan area are widespread, such as cracks in buildings and infrastructure due to differential settlements, subsided houses and buildings, increased coastal flooding, and inundation. Figure 2 shows some of the land subsidence impacts in the Pekalongan area superimposed on a land subsidence rate map from Chaussard et al. (2013).

The land subsidence phenomenon observed on the surface is the manifestation of the subsurface move- ment. Therefore, it is important to understand the subsurface condition. Previous studies on land subsidence in Pekalongan have not provided a clear understanding of the subsurface. The subsurface conditions related to land subsidence include depositional environment, lateral and vertical distribution of compressible strata, tectonics and seismicity.

\section{Depositional Environment of the Quaternary Deposit}

During the Holocene, the northern alluvial plain of Java Island experienced a significant coastal accretion during its development. Tjia (1968) analyzed the shoreline map from 1846-1946 and found that significant 


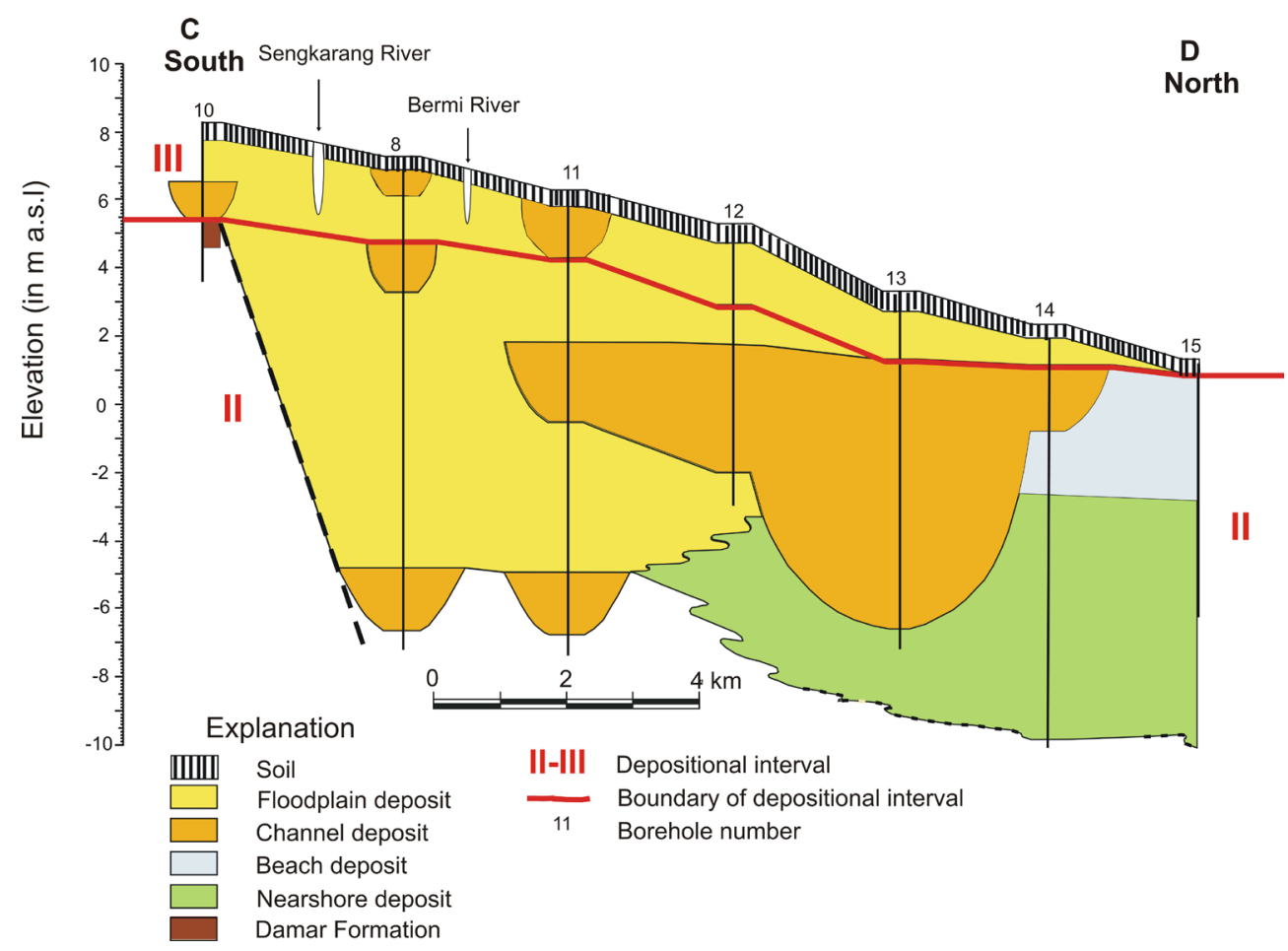

Figure 5: South-North section of the Quaternary sediment in Pekalongan (from Moechtar and Mulyana, 2010)

coastal accretion had occurred along the north central Java coast, like in the Pemali, Comal, Bodri, and Garang deltas. The factors influencing coastal accretion during this period are, but not limited to, denudation and volcanic activity, tectonics, postglacial sea-level change, local tides and waves, and changes in the drainage area. In Comal Delta, the Comal west area experienced coastal accretion of $31.5 \mathrm{~m}$ in 1870-1920, and coastal abrasion of $-61.5 \mathrm{~m}$ in 1920-1946, whereas in the Comal east area, abrasion of $-0.64 \mathrm{~m}$ occurred in $1870-1920$, and accretion of $145 \mathrm{~m}$ took place in 1920-1946, overall 66 $\mathrm{m} /$ year of coastal accretion was averaged (Tjia et al., 1968). It appeared that there had been a shifting of the river course from the west to the eastern part of the Comal River, forming the extensive alluvial plain east of the Comal River, now belonging to Pekalongan Regency administrative (see Figure 1).

Recent coastal accretion in the study area suggests that the alluvial deposit on the north coast of Java, including in Pekalongan, is of recent age, and may not have been fully consolidated. The deposition of Quaternary deposits in the study area is explained in detail by Moechtar et al.(2009) and Moechtar and Mulyana (2010), the methods used were shallow borings (up to the depth of $16 \mathrm{~m}$ ), carbon dating (C-14), and lithofacies analysis. Three cross-sections were analyzed from Moechtar et al. (2009) and Moechtar and Mulyana (2010), WE section and NW-SE section almost perpendicular to Comal, Sragi and Pekalongan rivers, and a NS section parallel to the Pekalongan River (see Figures 3, 4, and 5).
The Quaternary deposits from the shallow borings in Moechtar et.al (2009) and Moechtar and Mulyana (2010) are described as: the weathering of the Damar Formation (QTd), linear clastic deposits of offshore deposit, nearshore deposit, beach deposit, swamp deposit, and fluvial system deposit (channel and flood plain). Each facies is explained as the following:

- The weathered Damar Formation consists of yellowish to brownish grey, plastic, tuffaceous clay and tuff, with occasional yellow and red spots. Fragments of andesitic rocks are found within the clay which becomes more pronounced downward, therefore it is assumed that the Damar Formation forms the base of the Holocene clastic deposits.

- The offshore deposit is characterized by dark grey to greenish grey soft clay, highly plastic, containing foraminifera and mollusc shells, intercalated with thin sands.

- The nearshore deposit consists of brownish grey to greenish grey silt to sandy clay, sometimes humic, with mollusc and some foraminifera.

- The beach deposit consists of brownish white to light grey, fine to medium sand, well-sorted, with abundant molluscs.

- The swamp deposit is characterized by blackish grey, soft, organic silt, rarely sandy, humic, contains traces of roots and is sometimes intercalated with a peat layer.

- The channel deposit consists of coarse to fine sand, and gravels; the sand is dark brown to blackish 
grey, sub rounded to sub angular, medium sorted, non-laminated, sometimes contains organic matters and plant remnants. The channel deposit is marked by an erosional bed at the bottom and showing fining upward grainsize.

- The floodplain deposit is comprised of brown to grey clay laminated with thin sand with occasional yellow to reddish yellow iron concretions.

With the Damar Formation of Late Pleistocene as the base of the alluvial basin, the depositional sequence of the alluvial deposit strongly relates to the sea-level changes during the Holocene. Three depositional intervals were inferred by Moechtar et al. (2009) and Moechtar and Mulyana (2010), as explained in the following:

- Interval I started with the abrupt rise of postglacial sea-level resulting in the deposition of offshore deposit filling the bottom part of the basin (see Figure 3). Further away in the NW-SE section (see Figure 4), the offshore developed at the northwestern part, in the mid to the southeastern parts, the offshore deposit didn't develop because the elevation of the Damar Formation is higher than sea-level. As the Damar Formation is dipping to the North, the offshore deposit developed is filling the bottom part of Damar Formation in the north coastal area (Moechtar et al., 2009). Figure 5 shows that closer to the sea, the Interval I deposition would be found at a deeper elevation.

- Interval II started when the regression of sea-level began as indicated by the development of a fluvial system, marked by the development of a channel at the boundary between interval I and II (see Figures $\mathbf{3 , 4}$, and 5). Sediment supplies continued from the southern highland and as the sea-level continued to lower, shifting in river channels occurred and a floodplain developed (see Figures 4 and 5).Figures 3 and 4 indicate that there had been a shifting of the river channels forming a large floodplain to the east. The river channels and floodplain were well developed in the southeast (see Figure 4) and south (see Figure 5). Interfingering between the fluvial and beach and nearshore deposits are seen towards the north shore (see Figures3,4, and 5). At the north shore, river channels had not developed well, instead, the environment started to become the sea again as the sea-level rose forming nearshore deposit. When the sea level dropped again, beach and swamp deposits were formed (see Figures 3,4,and5). Figures 3 and 4 show that the swamp deposit occurred at elevation -1.0 to -1.5 m.s.l. Carbon dating results shows that the ages of the swamp deposit in Interval II are $5750 \pm 120$ to $4580 \pm 280$ B.P at the lower part and $2720 \pm 240$ to $2090 \pm 220$ B.P at the upper part (Moechtar et.al, 2009) (see Figure 3).

- Interval III started when the sea-level fell again causing the fluvial system to re-developed, flood plain and swamp were deposited and the river channel shifted.Carbon dating results shows that the age of the deposit in Interval III is between $1430 \pm 140$ B.P to $1180 \pm 130$ (Moechtar et.al, 2009) (see Figure 3).

The depositional environment of the Holocene sediment in Pekalongan explained by Moechtar et al. (2009) and Moechtar and Mulyana (2010) are strongly related to the fluctuation of the global sea-level rise.We attempt to correlate the carbon dating results (Moechtar et al., 2009) (see Figure 5) with the eustatic sea level from Fairbridge (1961). The depth of the Damar Formation in the Semarang north shore of the North Java coast is about 100-120 m (Sarah et al., 2020), similar to the sealevel during 20.000-18.000 B.P. We assume that the depth of the Damar Formation in Pekalongan is similar. Deposition of the offshore sediment on top of the Damar Formation during Interval I must have occurred any time after postglacial melting, causing transgression of the sea. The lower part of Interval II at $5750 \pm 120$ to $4580 \pm$ 280 B.P correlates with periods of sea level drops, forming the regressive fluvial system. The sea level rose again in $2720 \pm 240 \mathrm{BP}$, forming the nearshore deposit, and dropped in $2090 \pm 220$ B.P, forming beach and swamp deposits (see Figure 3). The sea level slightly rose afterwards and gradually fell back during 1500 to 750 B.P, during which the fluvial deposits in Interval III were deposited.

\section{Tectonics and Seismicity}

Tectonic activity in the Pekalongan area started in the Early Tertiary marked by uplift and erosion. Erosion products made up the sedimentary rocks of the Rambatan Formation and the Halang Formation deposited in the deep-marine environment and forming the basin filled by the Damar Formation in a transitional environment (Condon et al., 1996). Re-activation of tectonics during Plio-Pleistocene resulted in asymmetrical folds, followed by thrust fault trending relatively west-east, northeast-southwest, and northwest-southeast trending strike-slip faults, and a normal fault. The resulted fractured rocks became a weak zone, allowing for the intrusion of the Early Quaternary volcanic rocks (Jembangan Formation) (Qj) (see Figure 1).

Nainggolan (2009) carried out gravity and airborne magnetic surveys in the Pekalongan to Batang area to understand the subsurface geological structure.Regional Bouger anomaly indicated a strike-slip surface trending northwest-southeast.Gravity survey resulted in high and low anomalies of $\geq 10 \mathrm{mGal}$ and $\leq 10 \mathrm{mGal}$, respectively. The high gravity anomaly occupies the south and southeastern high of the Pekalongan - Batang area, while the low anomaly occupies most of the northern lowland area (see Figure 6). The magnetic survey resulted in a high anomaly of $\geq 125 \mathrm{nT}$ anda low anomaly $\leq$ $125 \mathrm{nT}$. The high anomaly indicated the existence of 


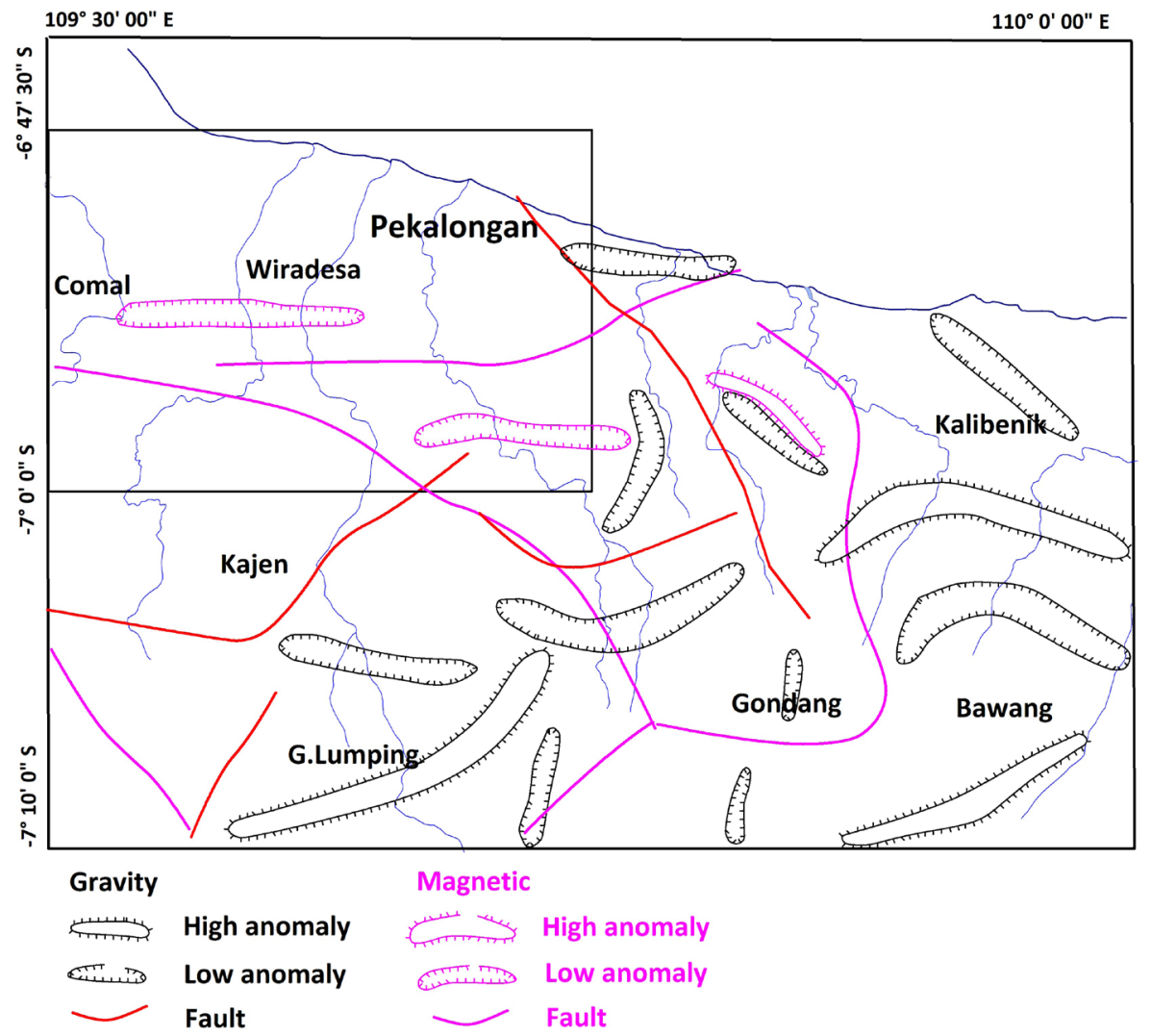

Figure 6: Summary of gravity and magnetic anomalies in Pekalongan-Batang (from Nainggolan, 2009)

magnetic rock and vice versa.Figure 6 shows that the Pekalongan area inside the blackbox mostly consists of low magnetic anomalies. Based on the interpretation of gravity and magnetic results, the Pekalongan area had undergone folding followed by faults cutting through the syncline and anticline. Low gravity and magnetic anomalies in north Pekalongan indicate the coastal basin influenced by geological structures trending NW-SE (strike-slip) and relatively WE (thrust).

Earthquakes in the Central Java region resulted from the megathrust subduction zone in the South Java Sea and shallow inland crustal faults.On average, 20 medium to large magnitude earthquakes occur each year (Ashadi et al., 2015). Most of the earthquakes occurred in South Java, meanwhile in North Java, the seismicity is lower. The Pekalongan area is under seismic threat from the active Baribis-Kendeng Fault. The BaribisKendeng Fault is a series of thrust faults and blindfolds elongate in the WE direction from West Java to Central and East Java (Simandjuntak \& Barber, 1996). In Pekalongan, the active fault extends for $16 \mathrm{~km}$ with a deformation rate of $4.5 \mathrm{~mm} /$ year (National Center for Earthquake Studies, 2017).A probabilistic earthquake hazard study by Ashadi et.al (2015) shows that the peak ground acceleration (PGA) in Pekalongan bedrock due to subduction and crustal fault-related earthquake is $0.14-0.15 \mathrm{~g}$ with a $10 \%$ probability of exceedance in 50 years corresponding to the return period of 475 years. These PGA values are among the lowest in Central Java province.

\section{Distribution of Compressible Strata}

Land subsidence takes place as the result of the compaction of compressible strata. Therefore, knowledge of the lateral and vertical distribution of compressible strata is fundamental to understanding the subsidence mechanism, particularly the overall areal extent and its resulting impacts. A minor problem is created when a basin subsides uniformly, except for the coastal area and areas near sensitive infrastructure. When vertical differential settlement occurs, potential destructive effects to buildings and infrastructures are expected(Burbey, 2002). Differential subsidence may result from the different thickness of compressible strata or the presence of a subsurface structure.

A river delta is comprised of sediments with various compressibility, clay and peat are the most compressible, followed by silt, while sand and gravels are the least to nearly not compressible (Freeze \& Cherry, 1979). Significant, inelastic compaction occurs in clay and peat, whereas small compactions in sand and gravels are chiefly very small, elastic, and recoverable (Galloway \& Burbey, 2011).A 1-D consolidation test generally as- 


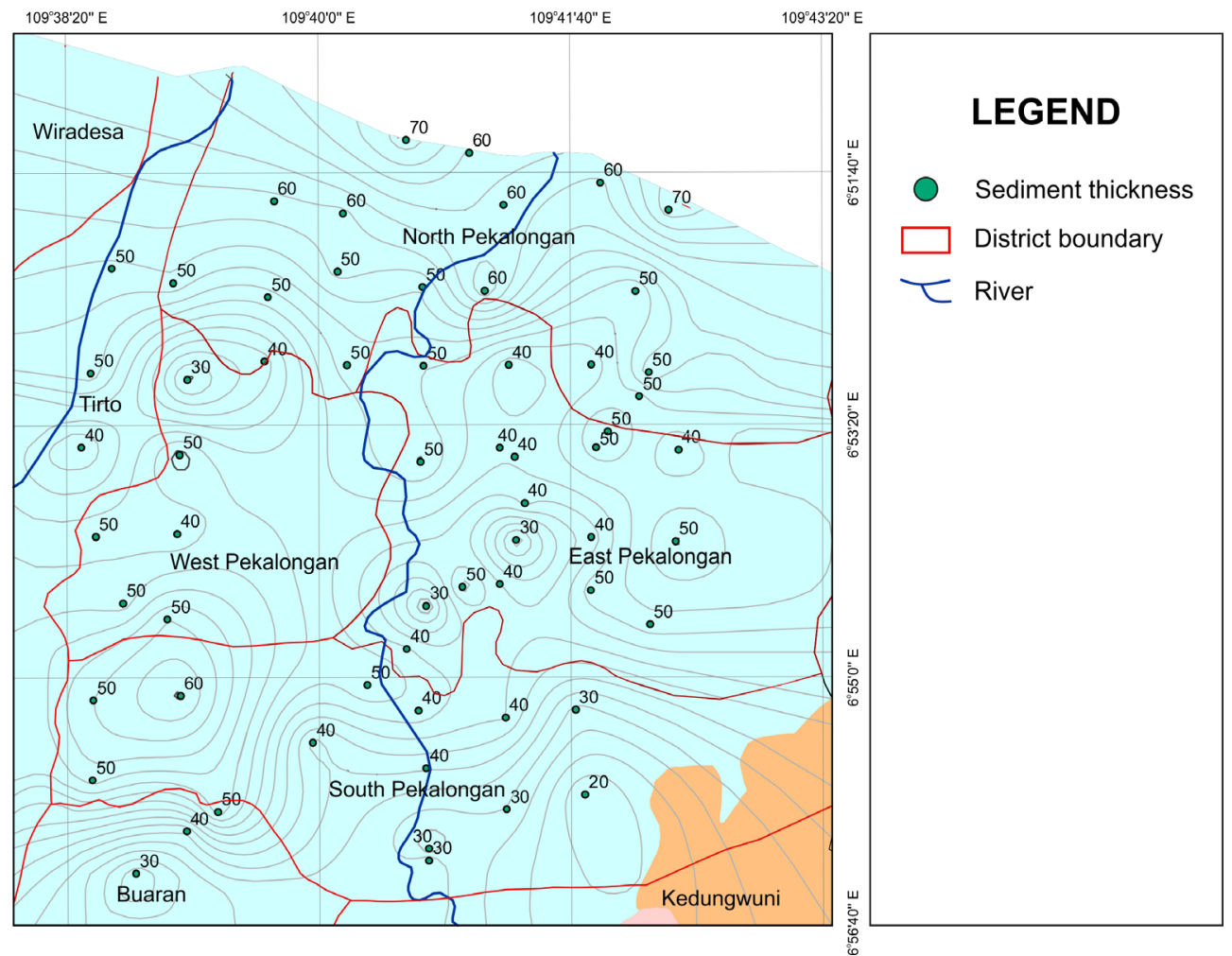

Figure 7: Map of soft sediment thickness in the Pekalongan area based on microtremor study (from Soehaimi et al., 2010)

sesses the compressibility of a clayey soil deposit by examining the coefficient of compression $\left(\mathrm{c}_{\mathrm{c}}\right.$ ) and coefficient of volume compressibility $\left(\mathrm{m}_{\mathrm{v}}\right)($ Bell, 2007; Craig, 2004). Characterization of soft soils can also be achieved by geotechnical in-situ tests, such as SPT and CPT tests (Cai et al., 2010; Desiani \& Rahardjo, 2017; Sivrikaya \& Toğrol, 2006), and geophysical surveys, such as resistivity (Giao, 2011) and microtremor (Delgado et al., 2000).

Early Holocene marine transgression in the Sunda Shelf resulted in a wide distribution of thick clays and peats in the deltaic areas of Southeast Asia(Cox, 1970; Sathiamurthy \& Voris, 2006). The thickness of soft clays in some deltas in Southeast Asia varies from 10-40 $\mathrm{m}$, such as in the Chao Phraya Delta (12-20 m) (Phienwej et al., 2006), Mekong Delta (18-40 m) (Minderhoud, 2019), Jakarta Delta (10-30 m) (Pranantya et al., 2017), and Semarang Delta (20-30 m) (Sarah et al., 2020). In the absence of geotechnical data of the Pekalongan region, the thickness of soft, compressible sediments can be predicted using the microtremor method. Soehaimi et al. (2010) carried out a microtremor survey in Pekalongan City to understand the subsurface amplification due to seismic threat from the active BaribisKendeng Fault.The soft sediment was taken as the soils with shear wave velocity $\mathrm{Vs} \leq 175 \mathrm{~m} / \mathrm{s}$, soft soil depth was calculated from Vs, and resonance frequency (f). The contour of soft sediment thickness from Soehaimi et al. (2010) is shown in Figure 7.
Figure 7 shows that the thickness of soft sediment varies from 30-70 $\mathrm{m}$, getting thicker to the north shore. Soft sedimentof a $50 \mathrm{~m}$ thickness in the south-west indicated the presence of a local basin in the area. Figure 7 shows a generalized spatial distribution of soft soils, as microtremor results cannot distinguish the type of lithology and the specific engineering characteristics.

\section{The Implication of Subsurface Condition to Land Subsidence Mechanism}

Land subsidence is principally a downward displacement of a discrete segment of the ground surface that can occur suddenly and gradually (Galloway et al., 1999). Land subsidence due to sudden collapse commonly occurs at the near surface zone, mainly due to a water pressure increase in the subsurface soil from water leaks from sewer pipes and water mains, and caving in underground mines(Ali \& Choi, 2020; Tichavský et al., 2020). In a natural setting, sudden collapse frequently occurs as a sinkhole due to the dissolution of carbonate and evaporite rocks in the subsurface (Calligaris et al., 2017; di Santolo et al., 2018). Gradual land subsidence mostly occurs due to natural compaction, aquifer system compaction induced by groundwater withdrawal (Chen et al., 2020; Xu et al., 2015), and the addition of surface loading (Li et al., 2019; Tang et al., 2008). The land subsidence in the Pekalongan area belongs to the second type. 
Natural compaction is common in recent sediments, especially in deltaic and marsh deposits (Liu et al., 2021; Stanley \& Corwin, 2013; Teatini et al., 2011; Törnqvist et al., 2008). Natural compaction occurs due to rapid sedimentation of mainly fine-grained sediments causing delayed pore pressure dissipation (Zoccarato et al., 2018). The low permeability of the fine-grained sediment results in slow dissipation of excess pore water pressure developed during sedimentation, hence slow, gradual subsidence.

Poland (1984) and Holzer and Galloway (2006) explain the mechanism of this land subsidence due to groundwater withdrawal, which principally involves the hydro-mechanical coupling of groundwater flow and stress-strain of the aquifer system. The generalized confined aquifer system consists of an aquifer sandwiched in the constraining aquitard layers (Freeze \& Cherry, 1979). The stress-strain behaviour of the aquifer system is governed by the effective stress principle (Terzhagi) (Clayton et al., 1995) that defines effective stress as the difference between total geostatic stress and the pore pressure. Effective stress relates to grain-to grain contact of the aquifer system. When groundwater is withdrawn from the aquifer, the pore pressure decreases; hence, the effective stress increases, i.e., pore volume reduction and compression (grain-to-grain contact).

The permeability of the layers controls the gradual nature of the land subsidence process of the aquifer system. Land subsidence occurs very slowly, may take years and even centuries to end. During the pumping of a confined aquifer, the water supplied to the well is derived from the deformation of the aquifer system, that is, the expansion of water and compression of the granular skeleton (Holzer and Galloway, 2006). When aquifer pumping lowers the piezometric pressure of the aquifer, a vertical head gradient occurs between the aquifer and aquitard layers. The excess pore pressure in the aquitard layer is released by dewatering causing compression of the aquitard.As the permeability of the aquitard layer is much lower (typically $10^{-7}$ to $10^{-10} \mathrm{~m} / \mathrm{s}$ ) than that of the aquifer (1 to $10^{-6} \mathrm{~m} / \mathrm{s}$ ) (Craig, 2004), the dewatering of the aquitard layer is very slow (i.e., gradual, slow subsidence).

In the aquifer system, the compressibility of the aquifer layers (sands and gravels) is two to four orders of magnitude lower than that of the aquitard (Freeze \& Cherry, 1979). Therefore, the aggregate of aquitard compressions contributes to most of the subsidence (Poland, 1984). When the pore pressure decrease does not exceed the preconsolidation stress of the aquitard, a small, elastic, reversible compaction is resulted. Preconsolidation pressure is the maximum pressure experienced by the clay in the past due to loading and unloading conditions (Day, 2010). The preconsolidation stress separates the elastic and reversible deformations from inelastic and irreversible deformations (Tomas, 2007). When water-level decline causes an increase in effective stress exceeding its preconsolidation stress, large, irrecoverable compaction occurs. Holzer (1981) demonstrated that several aquifer systems of unconsolidated to semi-consolidated deposits of late Cenozoic age in the United States had natural preconsolidated stress that required water levels to decline more than $30 \mathrm{~m}$ to undergo significant, permanent subsidence. The preconsolidation stress also explains why the land subsidence has become more pronounced after the twentieth century, since before man-induced, rapid water level decline, the subsidence was small and recoverable (Holzer \& Galloway, 2005). Similarly, in the case of the application of surface loading (i.e., land reclamation and building), when applied large loads exceed the preconsolidation pressure of the surface soil, large and irreversible subsidence occurs.

Ground deformation due to land subsidence is controlled by the basin structures, particularly continuous and discontinuous fracture zones or faults. Tectonic controls in land subsidence are mainly found in active tectonic settings involving normal faults, and sometimes strike-slip faults (Aliaj et al., 2001; Carreón-Freyre et al., 2016; Dokka, 2006; Hu et al., 2019). In those areas, the main subsidence bowls are located in grabens. Differential subsidence occurred at the fault boundary, where the hanging wall subsided more than the footwall. The differential subsidence can be attributed to the thicker sediments in the hanging wall or the discontinuity of the permeable zone in the fault fracture zone $\mathbf{~} \mathbf{H u}$ et al., 2019). Differential subsidence is detrimental to buildings and infrastructure as it can cause structural instability. Active fault movement can also affect the subsidence rate. Tectonic subsidence in Michoud normal fault accounted for $73 \%$ of total subsidence during the fault reactivation period in 1969-1971 and slowed down afterwards(Dokka, 2006).

The subsurface condition of the Pekalongan area has been explained in terms of its depositional environment, tectonics and seismicity, and spatial distribution of soft sediments. Therefore, a preliminary understanding of the Pekalongan subsurface is helpful to deduce the possible mechanisms of land subsidence, explained in the following section.

\subsection{Natural compaction}

Pekalongan area is built from deltaic sediments of clay, peat, silt, sand, and gravels of recent age capable of compacting under its own weight. Recent deltas in Southeast Asia such as the Semarang Delta (Sarah et al., 2020), Mekong Delta (Zoccarato et al., 2018), and Yellow Delta (Liu et al., 2021) are known to experience ongoing natural compaction. Compaction is a natural process during delta evolution. As the delta evolves, new sediments are deposited on top of the older layers. Gravitational loading of the overburden causes the sediment underneath to compact mechanically. Compaction could occur instantaneously and may continue long after the depositional process ceased. When the permeability of 
the underlying sediment is low (i.e., fine-grained sediment), delayed compaction due to overpressure dissipation occurs.Another mechanism of natural compaction involves the degradation of peaty deposits due to compression and oxidation of organic matter. The thick, soft deposit of recent age in Pekalongan (see Figures3,4, and5) is highly prone to natural compaction. It is likely that the offshore, nearshore, and swamp deposits (see Figures 3, 4, and 5) experience significant natural compaction due to delayed dissipation of overpressure and secondary compaction. Floodplain deposits may also experience natural compaction to a lesser degree. Intercalation of clay-silt and sand in a floodplain deposit facilitates the faster dissipation of pore water pressure. It is possible that the floodplain deposit has already compacted or is now still compacting at a lower rate. Further study to elaborate on the extent and magnitude of natural compaction is necessary.

\subsection{Land subsidence induced by groundwater over-exploitation}

Groundwater over-exploitation has generated land subsidence problems worldwide, in particular, that of a confined aquifer. Unconfined aquifers in the Pekalongan area are found in floodplain, beach, and channel deposits near the surface (see Figures 3, 4, and 5). As the fresh, unconfined groundwater is contaminated with saline water from coastal flooding (Widada, 2007), the use of a deeper, confined aquifer is inevitable.Deep groundwater in Pekalongan can be extracted from confined aquifers within the deltaic deposit and Damar Formation. Deltaic aquifers can be found in channel, beach, floodplain, nearshore, and offshore deposits (see Figures 3, 4, and 5). By the nature of their depositional environments, the freshwater aquifers are expected in the floodplain, channel, beach deposits, and the Damar Formation.

Pekalongan is known as an industrial centre on the north coast of Java. There is a mix of small, medium, and large industries in the fields of metal, machinery, chemical, agricultural products, textile, and batik, amounting to a total of 4,570 and 4,370 enterprises in 2017 and 2018, respectively (URL 3, 2021). Water supply for industrial and domestic uses is provided by the regional drinking water company (PDAM) and groundwater. According to a local survey (University of Pekalongan, 2018), domestic subscription to PDAM is less than $29 \%$ of the total domestic households in Pekalongan. Although water supply from PDAM to industries is specifically unknown, it is thought that medium to largesized industries rely on groundwater extracted from adepth of 100-120 m below the surface (Putranto et al., 2015). Confined groundwater in Pekalongan is heavily exploited by households and tourism, industries, and even the PDAM itself; the reliance of water supply from groundwater reaches $98 \%$, with only $2 \%$ coming from surface water (river and springs) (University of Pekalongan, 2018). Groundwater monitoring by the Central
Java provincial government(URL 4, 2021) in North Pekalongan reveals that piezometric head had decreased from $-44.69 \mathrm{~m}$ (2017) to $-50.46 \mathrm{~m}$ (2021) or an average of $1.44 \mathrm{~m}$ head drop per year. The stressed groundwater condition due to intense pumping is considered the main trigger of the high subsidence rate in the area. The current rate of subsidence (10-15 cm/year) (Andreaset al., 2019) is approximately one order of magnitude lower than the groundwater depletion rate. The high rate of groundwater level drop must have exceeded the natural preconsolidation stress, thus causing the speedy, irreversible land subsidence.

\subsection{Increase of built area}

An increase of the built area due to construction, such as housing settlements, office, and hotel towers, can cause land settlement due to consolidation of the subsurface soil. The addition of surface loadings like built structures adds weight to the ground. When stress is applied to saturated soil, the soil particles will compress more tightly, reducing their bulk volume, and excess pore water is expelled, resulting in consolidation settlement. This process is well explained as the 1-D Terzaghi consolidation theory (Craig, 2004). When drainage is required before construction work, it will also lead to hydro-compaction and consolidation settlement.The increase of built area is also causing a reduction of sediment aggradation, as built structures now occupy the flood plain. In nature, the floodplain is replenished through sedimentation by floods, and this builds a new sedimentary layer over the naturally subsiding strata.As the built-up area in Pekalongan is about $57.75 \%$ of the city area (Bashit et al., 2020), we cannot ignore the influence of building weights and their spatial distribution on the land subsidence rate.

\subsection{Tectonics}

$s$ and magnetic surveys (Nainggolan, 2009) revealed that the Pekalongan coastal basin is influenced by a NWSE strike-slip fault and a WE trending thrust.The WE Baribis-Kendeng active thrust fault is located approximately $31 \mathrm{~km}$ south of the Pekalongan coastal plain. Moechtar and Mulyana (2010) argued that the shifting of river channels during the depositional process was related to the vertical movements of the basin due to active tectonics.However, his hypothesis of an active geological structure in the Pekalongan Basin needs to be further proven by detailed subsurface studies, such as Quaternary paleoseismology. The thick sediments covering the Pekalongan Basin may have obscured the existence of subsurface structures. Seismic survey will be useful to reveal the existence of a buried fault. Generally, the seismic activity of Pekalongan is relatively small, as indicated by the low seismic hazard threat (Ashadi et al., 2015). Furthermore, GPS measurements across Java Island during 2011-2017 revealed zero tectonic move- 
ments in Pekalongan (Andreas et al., 2019b). It is, therefore, conservative to assume that the tectonic influence on land subsidence in Pekalongan is negligible.

\section{Conclusion and Recommendation for Future Research}

Land subsidence in Pekalongan has been going on at a similarly high rate to the big cities in Java. This phenomenon is scientifically fascinating, mainly due to the less population and regional development in the study area.Insight from the subsurface hasbeen explained based on previous studies in Quaternary geology and geophysics. The triggers of land subsidence in Pekalongan are natural compaction, intense groundwater exploitation, and consolidation settlement from building weights. The influence of tectonic to subsidence is temporarily omitted until the existence of an active fault is proven.The high subsidence rate is related to the larger thickness of the compressible deposit. Previous geodetic studies indicated that high subsidence rates occur at the north shore, where the thickest soft deposit exists.The depositional environment of the sediment showed that subsidence is likely to still occur in offshore, nearshore, swamp, and floodplain deposit.

Understanding the extent of the land subsidence problem requires detailed stratigraphic and engineering geological information on a local scale. Preliminary data from literature lacks in depth, stratigraphic details, and engineering properties. For this reason, studies on the subsurface geology, hydrogeology, and engineering properties of the deposits that represent the vertical and horizontal distribution of the alluvial deposit and Damar Formation aquifer must be carried out.The availability of these data will allow subsidence analysis and a prediction to be made. Aquifer monitoring and subsidence measurement play a crucial role in the land subsidence models.However, aquifer monitoring in Pekalongan is still minimal. Therefore, it is suggested to increase the quality of aquifer monitoring in terms of piezometric instrumentation and historical records of groundwater volume abstraction. Continuous monitoring of subsidence is vital to understand the downward deformation and to constrain the subsidence model prediction. It is recommended that various geodetic methods, such as GPS and SAR interferometry are complemented by ground-based monitoring, such as a borehole extensometer.

Further research in Pekalongan should be based on a sound regional geological model. Therefore, the first thing to completeis the construction ofa subsurface model. Cost-effective subsurface exploration should use a combination of the borehole, cone penetration tests, geophysical methods, and laboratory tests to achieve detailed stratigraphic and engineering properties at a spatial scale. There are still some unanswered fundamental research questions:which trigger contributes to subsidence the most and how much is its contribution, what is the future prediction of subsidence in the area, how subsidence will affect the flood risk, especially when combined with sea-level rise, and how subsidence affects the structures of housing, high rise building, and infrastructure. In conclusion, there are still many unknown aspects of land subsidence in Pekalongan, yet the preliminary information on the subsurface can provide valuable insight. Additionally, the implementation of future research recommendations is beneficial to assist in land subsidence mitigation.

\section{Acknowledgment}

This study was part of the research 'Vulnerability of the North Java coastal area to land subsidence: Case study of Pekalongan' funded by LIPI's COREMAPCTI. We are grateful to the grant from LIPI's COREMAP-CTI 2021-2022 (17/A/DK/2021).

\section{References}

Ali, H. and Choi, J. H. (2020): Risk prediction of sinkhole occurrence for different subsurface soil profiles due to leakage from underground sewer and water pipelines. Sustainability (Switzerland), 310, 12, 1-16.

Aliaj, S., Baldassarre, G. and Shkupi, D. (2001): Quaternary subsidence zones in Albania: Some case studies. Bulletin of Engineering Geologyand The Environment, 59,4, 313-318.

Andreas, H., Abidin, H.Z., Sarsito, D.A. and Pradipta, D. (2019a): Determining the initial time of anthropogenicsubsidence in urban area of Indonesia. IOP Conference Series: Earth and Environmental Science, 389, 012034.

Andreas, H., Hasanuddin, Z.A., Sarsito, D.A., Meilano, I. and Susilo, S. (2019b): Investigating the tectonic influence to the anthropogenic subsidence along northern coast of Java Island Indonesia using GNSS data sets. E3S Web of Conferences, 94, 1-9.

Andreas, H, Abidin, H.Z., Sarsito, D.A. and Pradipta, D. (2020): Remotes sensing capabilities on land subsidence and coastal water hazard and disaster studies. IOP Conference Series: Earth and Environmental Science, 500,1, $1-14$.

Ashadi, L., Harmoko, U., Yuliyanto, G. and Kaka, S.I. (2015): Probabilistic Seismic-Hazard Analysis for Central Java Province, Indonesia. Bulletin of Seismological Society of America, 105, 3, 1711-1720.

Bashit, N., Prasetyo, Y. and Sukmono, A. (2020): Analysis of Built-up Land Spatial Patterns Using Multitemporal Satellite Imagery in Pekalongan City. Journal of Applied Geospatial Information, 4, 2, 356-362.

Bell, F.G. (2007): Engineering Geology. Elsevier ButterworthHeinemann, Oxford UK, $581 \mathrm{p}$.

Burbey, T.J. (2002): The influence of faults in basin-fill deposits on land subsidence, Las Vegas Valley, Nevada, USA. Hydrogeology Journal, 10, 5, 525-538.

Cai, G., Liu, S. and Tong, L. (2010): Field evaluation of deformation characteristics of a lacustrine clay deposit using seismic piezocone tests. Engineering Geology, 116, 3-4, 251-260. 
Calligaris, C., Devoto, S. and Zini, L. (2017): Evaporite sinkholes of the Friuli Venezia Giulia region (NE Italy). Journal of Maps, 13, 2, 406-414.

Cao, A., Esteban, M., Valenzuela, V.P.B., Onuki, M., Takagi, H., Thao, N.D. and Tsuchiya, N. (2021): Future of Asian Deltaic Megacities under sea level rise and land subsidence: current adaptation pathways for Tokyo, Jakarta, Manila, and Ho Chi Minh City. Current Opinion in Environmental Sustainability, 50, 87-97.

Carreón-Freyre, D., Cerca, M., Ochoa-González, G., Teatini, P. and Zuñiga, F.R. (2016): Shearing along faults and stratigraphic joints controlled by land subsidence in the Valley of Queretaro, Mexico. Hydrogeology Journal, 24, 3, 657-674.

Chaussard, E., Amelung, F., Abidin, H., and Hong, S.H. (2013): Sinking cities in Indonesia: ALOS PALSAR detects rapid subsidence due to groundwater and gas extraction. Remote Sensing of Environment, 128, 150-161.

Chen, B., Gong, H., Chen, Y., Li, X., Zhou, C., Lei, K. and Zhu, L. (2020): Land subsidence and its relation with groundwater aquifers in Beijing Plain of China. Science of the Total Environment, 735, 1-11.

Church, J.A., P.U., Clark, A., Cazenave, J.M., Gregory, S,. Jevrejeva, A., Levermann, M.A., Merrifield, G.A., Milne, R.S., Nerem, P.D., Nunn, A.J., Payne, W.T,. Pfeffer, D., Stammer. and Unnikrishnan, A.S. (2013): Sea Level Change. In: Climate Change 2013 The Physical Science Basis. Contribution of Working Group I to the Fifth Assessment Report of the Intergovernmental Panel on Climate Change [Stocker, T.F.D., Qin, G.K., Plattner, M., Tignor, S.K., Allen, J., Boschung, A., Nauels, Y., Xia, Bex, V. and Midgley, P.M. (eds.)]. Cambridge University Press., 1137-1177, $1586 \mathrm{p}$.

Clayton, C.R.I., Steinhagen, H.M. and Powrie, W. (1995): Terzaghi's theory of consolidation, and the discovery of effective stress. Proceedings of the Institution of Civil Engineers: Geotechnical Engineering, 113, 191-205.

Condon, W.H., Pardiyanto, L., Ketner, K.R., Amin, T.C., Gafoer, S. and Samodra, H. (1996): Geological Map of Banjarnegara dan Pekalongan Quadrangles Central Java, Indonesian Geological Agency, Bandung.

Cox, J.B. (1970): The Distribution and Formation of Recent Sediment in South East Asia. The Second Southeast Asian Conference on Soil Engineering. Singapore: Southeast Asian Society of Soil Engineering, Asian Institute of Technology and University of Singapore, 29-47, 648 p.

Craig, R.F.(2004): Craig's Soil Mechanics (7th ed). Spon Press, Taylor \& Francis Group, London and New York, $458 \mathrm{p}$.

Day, R.W. (2010): Foundation Engineering Handbook: Design and Construction with the 2009 International Building Code. The McGraw-Hill Companies, New York, San Francisco, Washington, D.C., Auckland, Bogotá, Caracas, Lisbon, London, Madrid, Mexico City, Milan, Montreal, New Delhi, San Juan, Singapore, Sydney, Tokyo, Toronto, 1008 p.

Delgado, J., López Casado, C., Estévez, A., Giner, J., Cuenca, A. and Molina, S. (2000): Mapping soft soils in the Segura river valley (SE Spain): A case study of microtremors as an exploration tool. Journal of Applied Geophysics,45,1, 19-32.
Desiani, A. and Rahardjo, P.P. (2017): Characterization of Bandung soft clay. Electronic Journal of Geotechnical Engineering, 22, 11, 4377-4393.

de Wit, K., Lexmond, B.R., Stouthamer, E., Neussner, O., Dörr, N., Schenk, A., Minderhoud, P.S.J. (2021): Identifying causes of urban differential subsidence in the Vietnamese Mekong Delta by combining InSAR and field observations. Remote Sensing, 13, 1-33.

di Santolo, A.S., Forte, G. and Santo, A. (2018): Analysis of sinkhole triggering mechanisms in the hinterland of Naples (southern Italy). Engineering Geology, 237, 42-52.

Dokka, R.K. (2006): Modern-day tectonic subsidence in coastal Louisiana. Geology, 34, 281-284.

Ericson, J.P., Vörösmarty, C.J., Dingman, S.L., Ward, L.G. and Meybeck, M. (2006): Effective sea-level rise and deltas: Causes of change and human dimension implications. Global and Planetary Change, 50, 1-2, 63-82.

Fairbridge, R.W. (1961): Eustatic changes in sea level. Physics and Chemistry of the Earth, 4, 99-185.

Freeze, R.A. and Cherry, J.A.(1979): Groundwater. PrenticeHall, Englewood Cliffs, New Jersey, 604 p.

Galloway, D., Jones, D.R. and Ingebritsen, S.E. (1999): Land Subsidence in The United States. United States Geological Survey Circular 1182, US Geological Survey, Reston, Virginia, $15 \mathrm{p}$.

Galloway, D.L. and Burbey, T.J. (2011): Review: Regional land subsidence accompanying groundwater extraction. Hydrogeology Journal, 19, 8, 1459-1486.

Giao, P.H. (2011): Electric imaging (EI) of soft clay deposits in some East and Southeast Asian deltas. 14th Asian Regional Conference on Soil Mechanics and Geotechnical Engineering, 1-10.

Hakim, W.L., Achmad, A.R., Eom, J. and Lee, C.W. (2020): Land subsidence measurement of Jakarta coastal area using time series interferometry with Sentinel-1 SAR data. Journal of Coastal Research, 102, 75-81.

Herrera-García, G., Ezquerro, P., Tomas, R., Béjar-Pizarro, M., López-Vinielles, J., Rossi, M., Mateos, R.M., CarreónFreyre, D., Lambert, J., Teatini, P., Cabral-Cano, E., Erkens, G., Galloway, D., Hung, W-C., Kakar, N., Sneed, M., Tosi, L., Wang, H. and Ye, S. (2021): Mapping the global threat of land subsidence. Science, 371, 6524, 34-36.

Holzer, T.L. (1981): Preconsolidation stress of aquifer system in areas of induced land subsidence. Water Resources Management, 17,3, 693-704.

Holzer, T.L. and Galloway, D.L. (2005): Impacts of land subsidence caused by withdrawal of underground fluids in the United States. Reviews in Engineering Geology, 16, 87-99.

Hu, L., Dai, K., Xing, C., Li, Z., Tomás, R., Clark, B., Shi, X., Chen, M., Rui, Z. and Qiang, Q. (2019): Land subsidence in Beijing and its relationship with geological faults revealed by Sentinel-1 InSAR observations. International Journal of Applied Earth Observation and Geoinformation, 82, 101886.

Irawan, A.M., Marfai, M.A., Munawar, Nugraheni, I.R., Gustono, S.T., Rejeki, H.A., Widodo, A., Mahmudiah, R.R. and Faridatunnisa, M.(2021): Comparison between averaged and localised subsidence measurements for 
coastal floods projection in 2050 Semarang, Indonesia. Urban Climate, 35,100760.

Li, Z., Luo, Z., Wang, Q., Du, J., Lu, W. and Ning, D. (2019): A three-dimensional fluid-solid model, coupling high-rise building load and groundwater abstraction, for prediction of regional land subsidence. Hydrogeology Journal, 27, 4, $1515-1526$

Liu, Y., Liu, J., Xia, X., Bi, H., Huang, H., Ding, R. and Zhao, L. (2021): Land subsidence of the Yellow River Delta in China driven by river sediment compaction. Science of the Total Environment, 750, 142165.

Mimura, N. (2013): Sea-level rise caused by climate change and its implications for society. Proceedings of the Japan Academy Series B: Physical and Biological Sciences, 89, 7, 281-301.

Minderhoud, P.S.J. (2019): The Sinking Mega-Delta: Present and Future Subsidence of the Vietnamese Mekong Delta. Utrecht University, 204 p.

Moechtar, H., Mulyana, H. and Hidayat, S. (2009): Perubahan lingkungan dan karakter sistem pengendapan Plistosen Akhir - Holosen di Dataran Pantai Pekalongan, Jawa Tengah (Environmental changes and the characteristics of the Late Pleistocene - Holocene deposition system in the Pekalongan Coastal Plain, Central Java). Jurnal Sumberdaya Geologi, 19, 6, 377-395. (in Indonesian- English abstract)

Moechtar, H. and Mulyana, H. (2010): Respon sistem respon sistem fluvial terhadap perubahan iklim Pleistosen AkhirHolosen termasuk Siklus Milankovich, studi kasus Geologi Kuarter berdasarkan sspek sedimontologi dan stratigrafi di Dataran Rendah Pekalongan, Jawa Tengah. (Fluvial system response to Late Plistocene-Holocene climate change related to the Milankovitch Cycle, A case study of Quaternary geology based on sedimentological and stratigraphic aspects in the Coastal Lowlands of Pekalongan, Central Java). Jurnal Sumberdaya Geologi, 20, 5, 219-233. (in Indonesian- English abstract)

Nainggolan, D.A. (2009): Struktur geologi bawah permukaan Daerah Pekalongan dan sekitarnya berdasarkan analisis anomali gaya berat dan magnet (Subsurface geological structure of Pekalongan and its surrounding areas based on gravity and magnetic anomalies. Jurnal Sumberdaya Geologi, 19, 2, 127-138. (in Indonesian - English abstract)

National Center for Earthquake Studies. (2017): Peta Sumber dan Bahaya Gempa Indonesia Tahun 2017 (Maps of Earthquake Sources and Hazards in Indonesia Year 2017). Ministry for Public Works and Housing, Research Center for Housing and Settlements, 400 p. (in Indonesian)

Phien-wej, N., Giao, P.H. and Nutalaya, P. (2006): Land subsidence in Bangkok, Thailand. Engineering Geology, 82, 4, 187-201.

Poland, J.F. (1984): Mechanics of Land Subsidence due to Fluid Withdrawal. In: Poland, J.F \& Editors (eds.): Guidebook to Studies of Land Subsidence due to Ground-water Withdrawal. - United Nations Educational. Scientific, and Cultural Organization (UNESCO)., 37-54, 325 p.

Pranantya, P.A., Sukiyah, E. and Utomo, E.P. (2017): Modelling for groundwater extraction effect for Jakarta land sub- sidence. International Journal of Science and Research, 6,8, 184-190.

Putranto, T.T., Imam, M. and Widiarso, D. (2015): Studi kerentanan airtanah terhadap pemompaan di Kota Pekalongan, Provinsi Jawa Tengah (Study of groundwater vulnerability to pumping in Pekalongan City, Central Java Province). Seminar Nasional Kebumian Ke-8: AcademiaIndustry Linkage, 98-110. (in Indonesian)

Schmidt, C.W. (2015): Delta subsidence: An imminent threat to coastal populations. Environmental Health Perspective, 123, 8, A204-A209.

Sarah, D., Hutasoit, L.M., Delinom, R.M. and Sadisun, I.A. (2020): Natural compaction of Semarang Demak Alluvial Plain and its relationship to the present land subsidence. Indonesian Journal on Geoscience, 7,3, 273-289.

Sarah, D. and Soebowo, E. (2018): Land subsidence threats and its management in the North Coast of Java. IOP Conference Series: Earth and Environmental Science, 118, 012042.

Sathiamurthy, E. and Voris, K.H. (2006): Maps of Holocene sea level transgression and submerged lakes on the Sunda Shelf. The Natural History Journal of Chulalongkorn University, 2, 1-44.

Simandjuntak, T.O. and Barber, A.J. (1996): Contrasting tectonic styles in the neogene orogenic belts of Indonesia. Geological Society Special Publication, 106,185-201.

Sivrikaya, O. and Toğrol, E. (2006): Determination of undrained strength of fine-grained soils by means of SPT and its application in Turkey. Engineering Geology, 86, 1, 52-69.

Soehaimi, A., Marjiono and Kamawan. (2010): Mikrozonasi kerentanah bahaya boncangan gempa bumi Kota Pekalongan berdasarkan analisis mikrotremor (Microzonation of earthquake shaking hazard in Pekalongan City based on microtremor analysis). Sumber Daya Geologi, 20,5, 277290. (in Indonesian- English abstract)

Stanley, J.D. and Corwin, K.A. (2013): Measuring strata thicknesses in cores to assess recent sediment compaction and subsidence of Egypt's Nile delta coastal margin. Journal of Coastal Research, 288, 3), 657-670.

Syvitski, J.P.M. (2008): Deltas at risk. Sustainability Science, 3,1, 23-32.

Syvitski, J.P.M., Kettner, A.J., Overeem, I., Hutton, E.W.H., Hannon, M.T., Brakenridge, G.R., Day, J., Vörösmarty,C., Saito, Y., Giosan, L. and Nicholls, R.J. (2009): Sinking deltas due to human activities. Nature Geoscience, 2,10, 681-686.

Tang, Y.Q., Cui, Z.D., Wang, J.X., Lu, C. and Yan, X.X. (2008): Model test study of land subsidence caused by high-rise building group in Shanghai. Bulletin of Engineering Geology and the Environment, 67, 2, 173-179.

Teatini, P., Tosi, L. and Strozzi, T. (2011): Quantitative evidence that compaction of Holocene sediments drives the present land subsidence of the Po Delta, Italy. Journal of Geophysical Research: Solid Earth, 116, 8, 1-10.

Tichavský, R., Jiránková, E. and Fabiánová, A. (2020): Dating of mining-induced subsidence based on a combination of dendrogeomorphic methods and in situ monitoring. Engineering Geology, 272, 105650. 
Tjia, H.D., Asikin, S., \& Atmadja, R.S. (1968): Coastal accretion in Western Indonesia. Bulletin of National Institute of Geology and Mining, Bandung, 1,1, 15-45.

Törnqvist, T.E., Wallace, D.J., Storms, J.E.A., Wallinga, J., Van Dam, R.L., Blaauw, M., Derksen, M.S., Klerks, C.J.W., Meijneken, C.and Snijders E.M.A. (2008): Mississippi delta subsidence primarily caused by compaction of Holocene strata. Nature Geoscience, 1,3, 173-176.

University of Pekalongan, Faculty of Economy. (2018): Real Demand Survey PDAM (Real Demand Survey for Local Drinking Water Company (PDAM). Universitas Pekalongan, 49 p. (in Indonesian)

Van Bemmelen, R.W. (1949): The Geology of Indonesia (Vol IA). Martinus Nijhoff, The Hague, 799 p.

Widada, S. (2007): Gejala intrusi air laut di daerah pantai Kota Pekalongan (Indication of seawater intrusion in the coastal area of Pekalongan City). Ilmu Kelautan: Indonesian Journal of Marine Sciences, 12, 1, 45-52. (in Indonesian English abstract)

Xu, Y.S., Yuan, Y., Shen, S.L., Yin, Z.Y., Wu, H.N. and Ma, L. (2015): Investigation into subsidence hazards due to groundwater pumping from Aquifer II in Changzhou, China. Natural Hazards, 78,1, 281-296.

Zeitoun, D.G. and Wakshal, E. (2013): Land Subsidence Analysis in Urban Areas. Springer Environmental Science and Engineering, Dordrecht, $296 \mathrm{p}$.

Zoccarato, C., Minderhoud, P.S.J. and Teatini, P. (2018): The role of sedimentation and natural compaction in a prograding delta: insights from the mega Mekong delta, Vietnam. Scientific Reports, 8,1, 1-12.

URL1: https://pekalongankota.bps.go.id/dynamictable/2020/ 05/18/203/kepadatan-penduduk-kota-pekalongan-menurut-kecamatan-tahun-2019.html(accessed 10th April 2021)

URL 2: https://pekalongankab.bps.go.id/indicator/12/29/1/ jumlah-penduduk-total-.html(accessed 10th April 2021)

URL 3: https://pekalongankota.bps.go.id/indicator/9/288/1/ banyaknya-perusahaan-menurut-klasifikasi-industri-.html (accessed 12th April 2021)

URL 4: http://siat.esdm.jatengprov.go.id ( accessed 30th April 2021)

\section{SAŽETAK}

\section{Pregled hazarda prouzročenoga slijeganjem površine u delti Pekalongan, središnja Java: uvid iz podzemlja}

Slijeganje površine tla prijetnja je svim obalnim područjima, pa tako i obali sjeverne Jave. Niz područja u tome prostoru podložno je takvu slijeganju. Iznos toga spuštanja posebno je izražen u velikim gradovima područja Pekalongan. Taj iznos daleko nadilazi porast morske razine rezultirajući gubitkom kopna. Vrlo velik učinak takvih površinskih spuštanja odražava se također i u dubini. Zato je nužno razumjeti ispodpovršinske pojave kako bi se objasnilo samo spuštanje površine. Prethodna istraživanja tih pojava u Pekalonganu uglavnom su bila usmjerena na praćenje iznosa spuštanja, bez uvida u dubinske odnose. Ovdje je prikazana dubinska geologija istraživanoga područja, pregledom dostupne literature. Rezultati su pokazali kako se spuštanje događa u recentnoj aluvijalnoj ravnici Pekalongana, koja obuhvaća tlo debljine 30 - $70 \mathrm{~m}$. Jedan od mogućih uzroka spuštanja jest prirodno zbijanje, zatim pretjerana eksploatacija podzemnih voda te prevelika izgrađenost. Seizmičnost je prostora mala, stoga je i utjecaj tektonike na taj proces zanemariv. Nadalje, morski, priobalni i močvarni talozi podložni su recentnom, prirodnom zbijanju. Kako je pritok svježe, meteorske vode minimalan, dolazi do pretjerane eksploatacije vodonosnika formacije Damar u delti. Predložena su buduća tematska istraživanja kojima bi se smanjio utjecaj opasnosti proizišlih iz slijeganja.

\section{Ključne riječi:}

slijeganje tla, Pekalongan, podzemlje, aluvijalne naslage, zbijanje

\section{Author's contribution}

Dwi Sarah (Ph.D in Engineering Geology, researcher) completed the literature review and was in charge of writing this manuscript. Eko Soebowo (B.Sc in Geology, senior researcher) provided the depositional environment and tectonics analysis. Nugroho Aji Satriyo (Magister in Geology, researcher) provided spatial development analysis and the final preparation of this manuscript. 